\title{
PENGEMBANGAN KOMIK SEBAGAI MEDIA PEMBELAJARAN AKUNTANSI PADA KOMPETENSI DASAR PERSAMAAN DASAR AKUNTANSI \\ UNTUK SISWA SMA KELAS XI
}

Oleh:

Indriana Mei Listiyani ${ }^{1}$

Ani Widayati ${ }^{2}$

\begin{abstract}
Abstrak
Penelitian ini bertujuan: (1) Mengembangkan komik sebagai media pembelajaran akuntansi untuk siswa SMA kelas XI; (2) Mengetahui kelayakan komik akuntansi berdasarkan penilaian ahli materi, ahli media dan guru akuntansi; (3) Mengetahui pendapat siswa mengenai media pembelajaran berbentuk komik akuntansi (4) Mengetahui dampak penggunaan komik akuntansi pada pembelajaran akuntansi SMA Kelas XI melalui nilai tes siswa untuk kompetensi persamaan dasar akuntansi.

Penelitian ini merupakan jenis penelitian dan pengembangan (Research and Development) dalam pembelajaran Akuntansi di Sekolah Menengah Atas. Model pengembangan yang diterapkan terdiri atas; 1) tahap analisis kebutuhan, 2) tahap desain produk, 3) tahap produksi, 4) tahap validasi dan evaluasi, 5) tahap revisi, 6) tahap uji coba produk, serta 7) tahap analisis dan revisi akhir. Tahap validasi dilakukan dengan validasi produk yang dilakukan oleh ahli materi akuntansi, ahli media pembelajaran dan praktisi pembelajaran akuntansi SMA yaitu guru akuntansi SMAN I Candimulyo. Produk yang dikembangkan diujicobakan pada 24 siswa kelas XI SMAN 1 Candimulyo. Pengumpulan data dilakukan dengan angket dan tes. Angket kelayakan untuk ahli dan praktisi, angket pendapat dan soal tes ditujukan kepada siswa.

Hasil penelitian menunjukkan bahwa media pembelajaran berbentuk Komik Akuntansi ini sangat layak untuk digunakan, terbukti dengan skor penilaian oleh ahli materi dengan jumlah 131,11 atau sebesar 87,54\% (sangat baik), skor penilaian ahli media jumlah 105,50 atau sebesar $92 \%$ (sangat baik) dan skor penilaian oleh praktisi pembelajaran dengan jumlah 169 atau sebesar 99,39\% (sangat baik). Pada ujicoba lapangan pembelajaran dengan menggunakan komik akuntansi, berhasil meningkatkan rata-rata nilai test siswa dari 51,88 manjadi 92,5. Dengan demikian, media pembelajaran berbentuk komik ini sangat layak digunakan untuk pembelajaran akuntansi di SMA Kelas XI.

Kata Kunci: Komik Akuntansi, Media Pembelajaran, Persamaan Dasar Akuntansi.
\end{abstract}

\footnotetext{
${ }^{1}$ Alumni Program Studi Pendidikan Akuntansi UNY

${ }^{2}$ Dosen Jurusan Pendidikan Akuntansi UNY
} 


\section{A. Pendahuluan}

\section{Latar Belakang Masalah}

Pendidikan merupakan ujung tombak suatu negara yang menginginkan sebuah masyarakat yang memiliki pemikiran, sikap serta tindakan yang mampu mendukung gerak negara tersebut ke arah yang lebih baik. Keberhasilan pendidikan akan menentukan perkembangan suatu negara menuju kemandirian dalam semua bidang kehidupan. Salah satu indikator keberhasilan pendidikan adalah terbentuknya individu yang cakap dan mandiri melalui suatu proses belajar. Keberhasilan proses belajar sendiri dapat ditandai dengan adanya perubahan tingkah laku individu menuju hal yang lebih baik. Muhibin Syah dalam Elis Mediawati (2011:68) mendefinisikan belajar sebagai tahapan perubahan tingkah laku individu yang relatif menetap sebagai hasil pengalaman dan interaksi dengan lingkungan yang melibatkan proses kognitif.

Keberhasilan proses pembelajaran ditentukan oleh ketiga aspek utama yaitu peserta didik (siswa), pendidik (guru) dan sumber belajar (materi). Namun, saat ini yang sering menjadi masalah adalah belum terdapatnya keselarasan antara ketiga aspek dalam proses pembelajaran tersebut. Beberapa bentuk dari ketidakselarasan ini diantaranya verbalisme, salah tafsir, perhatian tidak berpusat dan tidak terjadinya pemahaman (I Wayan Satyasa, 2007:5).

Berbagai permasalahan di atas merupakan akibat dari belum optimalnya proses komunikasi dua arah antara pendidik dan peserta didik dalam proses pembelajaran. Oleh karena proses pembelajaran merupakan proses komunikasi dan berlangsung pada suatu sistem, maka media pembelajaran menempati posisi yang cukup penting sebagai salah satu komponen sistem pembelajaran. Posisi media ini akan berlaku pada proses pembelajaran di semua cabang ilmu pengetahuan sesuai dengan karakteristik masing-masing ilmu.

Akuntansi merupakan salah satu cabang ilmu sosial yang cukup unik dibandingkan dengan ilmu sosial yang lain karena di dalamnya dipelajari seni dalam pencatatan keuangan. Mata pelajaran ini sering dianggap sebagai mata pelajaran yang membosankan bagi siswa. Anggapan bahwa akuntansi adalah mata pelajaran yang sulit, rumit dan membosankan ini salah satunya dipengaruhi oleh penggunaan media yang tidak tepat dalam proses belajar mengajar. 


\section{Jurnal Pendidikan Akuntansi Indonesia, Vol. X, No. 2, Tahun 2012 Indriana Mei Listiyani \& Ani Widayati \\ Halaman 80 - 94}

Pentingnya peran media pembelajaran dalam proses pembelajaran, menuntut seorang guru akuntansi untuk mampu menggunakan media yang menarik sehingga menciptakan motivasi yang tinggi bagi siswa untuk mempelajari akuntansi. Selain mampu menggunakan, hendaknya guru mengerti kharakteristik dan keefektifan dari media yang berbeda-beda dalam mendukung penyampaian materi.

Berdasarkan hasil observasi, pengamatan dan wawancara pada beberapa sekolah mengenai proses pembelajaran akuntansi, diperoleh beberapa fakta bahwa penggunaan media pada pembelajaran akuntansi masih terbatas pada buku paket dan soal-soal latihan yang diberikan oleh guru. Pada pembelajaran akuntansi di SMA, yang secara struktur kurikulum masih bergabung dengan mata pelajaran ekonomi, guru cenderung sangat sedikit memberikan penanaman konsep secara matang. Pembelajaran lebih didominasi oleh pemberian latihanlatihan soal. Metode pembelajaran ini bertujuan untuk membiasakan siswa mengerjakan soal sehingga nantinya saat ujian siswa mendapat nilai yang memuaskan. Hal ini tentu memiliki beberapa efek negatif bagi proses belajar siswa diantaranya; siswa hanya terbiasa menghafal penyelesaian soal yang sejenis dengan yang biasa diberikan oleh guru sehingga suatu ketika menemui soal yang berbeda siswa akan kebingungan, dalam pembelajaran siswa memang terlihat aktif mengerjakan soal akan tetapi dalam diri siswa belum ada proses konstruksi dari konsep akuntansi tersebut.

Dewasa ini telah dikembangkan berbagai macam media terutama yang lebih bersifat visual ataupun audio visual. Pengembangan ini berupaya mendukung potensi siswa secara umum yang secara alami dalam belajar lebih banyak menggunakan indera penglihatan yaitu mata. Selain penekanan pada sisi visual, media yang lebih di dukung untuk dikembangkan adalah media yang mendukung pembelajaran yang menyenangkan. Hal ini dimaksudkan agar siswa mau mengikuti pembelajaran dengan antusias, sehingga mata pelajaran yang dipelajari akan lebih mudah terekam pada memori siswa. Dan salah satu bentuk media itu adalah komik pembelajaran.

Komik merupakan suatu bentuk bacaan di mana peserta didik diharap mau membaca tanpa perasaan terpaksa/harus dibujuk (Nana Sudjana dan Ahmad Rivai, 2005:68). Hal ini tentunya tidak terlepas dari anggapan bahwa cerita komik lebih mudah dicerna dengan bantuan gambar yang ada di dalamnya. Kelebihan dari bacaan yang berbentuk komik ini telah banyak dimanfaatkan oleh negara-negara maju sebagai alat untuk meningkatkan minat baca 
anak pada buku-buku pelajaran. Salah satu negara yang telah memanfaatkan komik sebagai salah satu pendukung keberhasilan pendidikannya adalah Jepang (Romi Satria, 2008). Di negara ini, komik bukan merupakan benda asing yang digunakan sebagai media dalam pembelajaran. Bahkan, beberapa buku sekolah di Jepang diterbitkan dalam bentuk komik. Kenyataannya, komik menjadi media pembelajaran yang sangat efektif dan sangat diminati siswa dengan gambar dan cara bertuturnya yang lugas.

Selain di Jepang, pemanfaatan komik sebagai media pembelajaran juga telah banyak dilakukan oleh praktisi pembelajaran di Indonesia. Komik telah banyak dimanfaatkan untuk keperluan pembelajaran di dalam kelas, maupun sebagai media penyuluhan bagi masyarakat mengenai topik-topik tertentu. Saat ini, di Indonesia telah beredar komik pembelajaran yang dibukukan, tetapi lebih banyak didominasi oleh komik untuk pembelajaran ilmu pengetahuan alam dan matematika. Respon dari masyarakat terhadap komik pembelajaran ini positif dan komik pembelajaran ini dianggap mampu membantu siswa untuk lebih mudah mempelajari konsep-konsep pelajaran yang sebelumnya dianggap sulit untuk dipahami.

Berdasarkan pengamatan akan pentingnya media pembelajaran, anggapan bahwa akuntansi adalah mata pelajaran yang cukup sulit, dan keberhasilan komik pembelajaran menghadirkan suasana pembelajaran yang lebih menyenangkan bagi siswa pada beberapa mata pelajaran, maka pengembang bermaksud untuk mengembangkan media pembelajaran berbentuk komik akuntansi. Pengembangan komik sebagai media pembelajaran akuntansi ini diharapkan dapat mempermudah siswa untuk memahami konsep-konsep dasar yang dibutuhkan dalam mempelajari akuntansi, mengatasi kebosanan siswa pada proses pembelajaran yang monoton dan mengurangi kejenuhan siswa pada media pembelajaran akuntansi yang kurang variatif.

\section{Masalah Penelitian}

Berdasarkan pembatasan masalah di atas, maka dapat dibuat rumusan masalah sebagai berikut:

a. Bagaimanakah mengembangkan komik sebagai media pembelajaran akuntansi untuk siswa SMA kelas XI?

b. Bagaimanakah kelayakan produk komik akuntansi pada kompetensi dasar persamaan dasar akuntansi untuk siswa SMA kelas XI ini berdasarkan penilaian/validasi dari ahli 
materi, ahli media dan praktisi pembelajaran akuntansi (guru akuntansi SMA)?

c. Bagaimanakah pendapat siswa mengenai media pembelajaran berbentuk Komik Akuntansi?

d. Bagaimanakah dampak penggunaan media berbentuk Komik Akuntansi terhadap hasil tes akuntansi siswa SMA Kelas XI pada kompetensi dasar persamaan dasar akuntansi?

\section{Tujuan Penelitian}

Berdasarkan rumusan masalah yang telah dikemukakan di atas, maka dapat dirumuskan tujuan yang ingin dicapai dari penelitian ini yaitu sebagai berikut:

a. Mengembangkan komik sebagai media pembelajaran akuntansi untuk siswa SMA kelas XI.

b. Mengetahui kelayakan komik akuntansi berdasarkan penilaian ahli materi, ahli media dan guru akuntansi.

c. Mengetahui pendapat siswa mengenai media pembelajaran berbentuk komik akuntansi.

d. Mengetahui efek penggunaan komik akuntansi terhadap prestasi belajar akuntansi siswa SMA Kelas XI melalui nilai tes siswa untuk kompetensi persamaan dasar akuntansi.

\section{Kajian Pustaka}

\section{a. Media Pembelajaran}

Kata media berasal dari bahasa latin dan merupakan bentuk jamak dari kata medium yang secara harfiah berarti perantara atau pengantar. Menurut Gerlach dan Ely sebagaimana yang dikutip oleh Azhar Arsyad (2011: 3), Media apabila dipahami secara garis besar adalah manusia, materi atau kejadian yang membangun kondisi yang membuat siswa mampu memperoleh pengetahuan, keterampilan atau sikap. Pengertian media dalam proses belajarmengajar cenderung diartikan sebagai alat-alat grafis, photografis atau elektronis untuk menangkap, memproses dan menyusun kembali informasi visual atau verbal.

\section{b. Akuntansi}

Menurut AICPA (American Institute of Certified Public Accountans) dalam Zaki Baridwan (2008: 1) Akuntansi adalah suatu kegiatan jasa. Fungsinya adalah menyediakan data kuantitatif, terutama yang mempunyai sifat keuangan dari kesatuan usaha ekonomi yang 
dapat digunakan dalam pengambilan keputusan-keputusan ekonomi dalam memilih alternatifalternatif dari suatu keadaan.

\section{c. Komik}

Menurut Nana Sudjana dan Ahmad Rivai (2005: 64), komik adalah suatu bentuk kartun yang mengungkapkan karakter dan memerankan suatu cerita dalam urutan yang erat dihubungkan dengan gambar untuk memberikan hiburan kepada para pembacanya. Predikat menghibur dan menyenangkan telah melekat pada komik semenjak awal kemunculannya pada tahun 1980-an.

\section{B. Metode Penelitian}

\section{Jenis Penelitian}

Penelitian ini termasuk penelitian pengembangan (Research and Development) model Borg \& Gall (1983:775) yang disederhanakan. Prosedur yang dilakukan dalam penelitian pengembangan ini:

1) Tahap Analisis Kebutuhan.

2) Tahap Desain Produk.

3) Tahap Produksi/ Pelaksanaan Pengembangan Produk.

4) Tahap Validasi.

5) Tahap Revisi.

6) Uji Coba Produk.

7) Analisis dan Revisi Terakhir.

\section{Validasi dan Uji Coba Produk}

\section{a. Desain Validasi}

Validasi produk dilakukan dalam beberapa tahap:

1) Instrumen yang telah disusun berupa angket kelayakan komik, angket pendapat siswa tentang komik, serta soal pretest dan posttest siswa dikonsultasikan kepada dosen pembimbing, sehingga diperoleh instrumen yang valid.

2) Instrumen yang telah valid beserta Komik Akuntansi yang telah disusun diserahkan kepada ahli materi untuk divalidasi dan dikoreksi mengenai kesesuaiannya dengan materi persamaan dasar akuntansi. 
3) Berdasarkan kritik dan saran dari ahli materi dilakukan revisi I.

4) Komik Akuntansi revisi yang telah lulus validasi dari ahli materi diserahkan kepada ahli media untuk divalidasi dan dikoreksi mengenai kesesuaiannya dengan kriteria media pembelajaran yang baik.

5) Berdasarkan kritik dan saran dari ahli media dilakukan revisi II.

6) Komik Akuntansi yang telah dinyatakan layak oleh ahli materi dan ahli media divalidasi oleh praktisi pembelajaran akuntansi. Praktisi juga diminta untuk melakukan validasi untuk mengukur kesesuaian media untuk diimplementasikan pada proses pembelajaran di SMA Kelas XI.

7) Jika praktisi pembelajaran akuntansi juga memberikan koreksi terhadap Komik Akuntansi, maka akan dilakukan revisi III. Namun, jika praktisi tidak memberikan revisi terhadap produk, komik akuntansi langsung dapat diujicobakan kepada siswa.

8) Komik Akuntansi yang telah melalui keseluruhan tahap validasi dan dinyatakan layak diujicobakan pada siswa.

9) Analisis terhadap hasil uji coba, jika ada masukan dari siswa mengenai komik yang bisa dilaksanakan (tidak bertentangan dengan saran dari para validator), maka akan dilakukan Revisi IV.

\section{b. Validator dan Subjek Uji Coba}

Validator pada penelitian ini adalah 3 ahli materi akuntansi (Dosen Jurusan Pendidikan Akuntansi UNY); 2 ahli media pembelajaran (Dosen Jurusan Pendidikan Akuntansi UNY dan Dosen Jurusan Kurikulum dan Teknologi Pendidikan); serta 1 praktisi pembelajaran akuntansi (Guru Akuntansi SMAN I Candimulyo). Subjek uji coba dalam penelitian ini adalah siswa kelas XI IPS 3 SMAN I Candimulyo, Magelang.

\section{Teknik Pengumpulan Data}

a) Kuesioner.

b) Soal Tes.

\section{Teknik Analisis Data}

Data yang terkumpul akan dianalisis untuk mengetahui kualitas produk pengembangan yang dihasilkan. Data berupa saran maupun kritik dari para ahli, guru SMA 
dan siswa dianalisis dengan pendekatan kualitatif, sedangkan data mengenai kelayakan komik akan dianalisis dengan pendekatan deskriptif kuantitatif. Data kelayakan dari tiap indikator disajikan dalam skala 5 dengan kriteria sebagai berikut:

$5=$ jika $80 \%-100 \%$ kriteria kelayakan dari indikator telah terpenuhi.

$4=$ jika $60 \%-79 \%$ kriteria kelayakan dari indikator telah terpenuhi.

$3=$ jika $40 \%-59 \%$ kriteria kelayakan dari indikator telah terpenuhi.

$2=$ jika $20 \%-30 \%$ kriteria kelayakan dari indikator telah terpenuhi.

$1=$ jika kriteria kelayakan yang terpenuhi dari indikator masih kurang dari $20 \%$.

Selanjutnya data kelayakan melewati beberapa tahapan analisis dengan langkahlangkah sebagai berikut:

1. Melakukan tabulasi/ rekapitulasi data hasil penelitian.

2. Menghitung skor rata-rata dari instrumen dengan rumus:

$\bar{X}=\frac{\sum x}{N}$

Keterangan:

$\bar{X} \quad=$ Skor rata-rata.

$\sum x=$ Jumlah skor.

$N=$ = Jumlah subjek uji coba.

3. Menginterpretasi secara kualitatif jumlah rerata skor tiap aspek dengan menggunakan rumus konversi skala 5 (Penilaian Acuan Kriteria/ Criterian Reference Evaluation) dengan ketentuan sebagai berikut:

Tabel 1. Rumus Konversi Jumlah Rerata Skor Menjadi Nilai dengan Lima

Kategori.

\begin{tabular}{|c|c|c|c|}
\hline Skor & Interval Skor & Nilai & Kategori \\
\hline 1. & ${ }_{\text {Dat }} \mathrm{Sbi}<\mathrm{X}$ & A & Sangat Baik \\
\hline 2. & 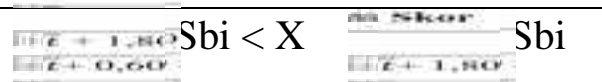 & B & Baik \\
\hline 3. & $\begin{array}{c}t+0.00 \\
t-0.00\end{array}$ & $\mathrm{C}$ & Cukup \\
\hline 4. & 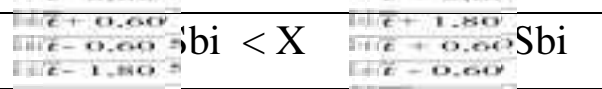 & $\mathrm{D}$ & Kurang \\
\hline 5. & 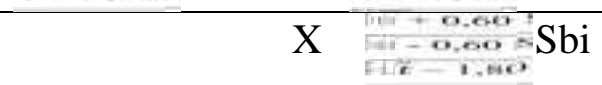 & $\mathrm{E}$ & Sangat Kurang \\
\hline
\end{tabular}

Sumber: Sukardjo(2005: 53) 
Keterangan

1. Skor Maksimal

2. Skor Minimal

3. Skor Maksimal Ideal

4. Skor Minimal Ideal

5. $X$

6. Rerata Ideal

7. Simpangan baku skor ideal (Sbi)
$=5$.

$=1$.

$=$ Jumlah Indikator x Skor Tertinggi.

$=$ Jumlah Indikator x Skor Terendah.

$=$ Skor yang diperoleh.

$=\frac{1}{2}($ skor maks.ideal+skor min.ideal $)$.

$=\frac{1}{6}($ skor maks.ideal-skor min.ideal $)$.

Berdasarkan tabel konversi di atas diperoleh standar kualitas produk komik akuntansi di tiap aspeknya secara rata-rata dengan rincian sebagai berikut:

1. Kualitas komik akuntansi yang dikembangkan dilihat dari tiap aspeknya dinyatakan sangat bagus (A) bila rata-rata skor yang diperoleh antara 4,21 sampai dengan 5,00.

2. Kualitas komik akuntansi yang dikembangkan dilihat dari tiap aspeknya dinyatakan bagus (B) bila rata-rata skor yang diperoleh antara 3,41 sampai dengan 4,20.

3. Kualitas komik akuntansi yang dikembangkan dilihat dari tiap aspeknya dinyatakan cukup bagus (C) bila rata-rata skor yang diperoleh antara 2,61 sampai dengan 3,40.

4. Kualitas komik akuntansi yang dikembangkan dilihat dari tiap aspeknya dinyatakan kurang bagus $(\mathrm{K})$ bila rata-rata skor yang diperoleh antara 1,81 sampai dengan 2,60.

5. Kualitas komik akuntansi yang dikembangkan dilihat dari tiap aspeknya dinyatakan sangat bagus (SK) bila rata-rata skor yang diperoleh antara 1,00 sampai dengan 1,80.

Selain kriteria di atas, dapat pula ditentukan kriteria kelayakan komik secara keseluruhan yaitu dengan mengalikan skor penilaian dengan jumlah indikator yang diukur di setiap aspek yang dinilai. Untuk keperluan analisis lebih lanjut seperti membandingkan hasil penilaian tiap aspek dengan tingkat kelayakan yang diharapkan, digunakan teknik presentase dalam menganalisis data dengan rumus sebagai berikut:

Presentase kelayakan tiap aspek $(\%)=\frac{\sum \text { rerata Skor yang diperoleh }}{\Sigma \text { rerata Skor yang ideal }} \times 100 \%$

Data yang terkumpul dianalisis dengan teknik analisis deskriptif kuantitatif yang diungkapkan dalam distribusi skor dan presentase terhadap kategori skala penilaian yang telah ditentukan. Setelah penyajian dalam bentuk presentase, langkah selanjutnya 
mendeskripsikan dan mengambil kesimpulan tentang masing-masing indikator. Kesesuaian aspek dalam pengembangan media pembelajaran dapat menggunakan table sebagai berikut Tabel 2. Tabel Skala Presentase Penilaian

\begin{tabular}{|c|c|}
\hline Presentase Penilaian & Interpretasi \\
\hline $81-100 \%$ & Sangat Layak \\
\hline $61-80 \%$ & Layak \\
\hline $41-60 \%$ & Cukup Layak \\
\hline $21-40 \%$ & Kurang layak \\
\hline $0-20 \%$ & Tidak Layak \\
\hline
\end{tabular}

Sumber: Suharsimi Arikunto (2010: 44)

Pada tabel 2 di atas disebutkan kriteria presentase penilaian dan intrepretasi. Untuk mengetahui kelayakan digunakan tabel di atas sebagai acuan penilaian data yang dihasilkan dari ahli media, ahli materi dan Guru mata pelajaran Ekonomi (Akuntansi).

Data mengenai hasil tes siswa (pre-test dan post-test) akan dianalisis dengan dengan membandingkan jumlah siswa yang mencapai KKM dari kedua tes tersebut. Kemudian dilihat presentase kenaikan jumlah siswa yang mencapai KKM. Data berupa komentar siswa mengenai komik akan dianalisis dengan analisis item dengan mengelompokkan jawaban di tiap item (nomer soal) berdasarkan kategori dari jawaban mereka yaitu sebagai berikut:

1. Untuk jawaban pertanyaan nomer 1 dikelompokkan pada kategori jawaban sangat jelas, jelas, cukup jelas, kurang jelas dan tidak jelas.

2. Untuk jawaban pertanyaan nomer 2 dikelompokkan pada kategori jawaban sangat mudah dipahami, mudah dipahami, cukup mudah dipahami dan susah dipahami.

3. Untuk jawaban pertanyaan nomer 3 dikelompokkan pada kategori jawaban sangat mendorong, mendorong, cukup mendorong dan kurang mendorong.

4. Untuk jawaban pertanyaan nomer 4 dikelompokkan pada kategori jawaban sangat menambah pengetahuan, menambah pengetahuan, cukup menambah pengetahuan dan tidak menambah pengetahuan.

5. Untuk jawaban pertanyaan nomer 5 dikelompokkan pada kategori jawaban sangat menambah wawasan, menambah wawasan, cukup menambah wawasan dan tidak menambah wawasan. 
6. Untuk jawaban pertanyaan nomer 6 dikelompokkan pada kategori jawaban sangat jelas, jelas, cukup jelas dan tidak jelas.

7. Untuk jawaban pertanyaan nomer 7 dikelompokkan pada kategori jawaban sangat mudah dibaca, mudah dibaca, cukup mudah dibaca dan sulit dibaca.

\section{Hasil Penelitian dan Pembahasan}

Komik Akuntansi yang telah diproduksi telah melewati tahap validasi untuk mengetahui kelayakan. Setelah media dinyatakan layak oleh masing-masing validator, media diujicobakan pada siswa Kelas XI IPS 3 SMAN I Candimulyo. Berikut adalah pembahasan masing-masing pengujian kelayakan media:

\section{Pengujian Kelayakan Media Pembelajaran}

a. Ahli Materi

Hasil penilaian oleh ahli materi ditinjau dari acuan kriteria (Sukardjo, 2005:53) adalah sebesar 131,33 sehingga dapat disimpulkan bahwa kualitas komik masuk pada kategori "sangat baik". Jika dilihat dari penilaian berdasarkan persentase tiap aspek; (1) Isi 87\%; (2) Kebahasaan: 89\%; (3) Penyajian 91\%; (4) Efek Media terhadap Strategi Pembelajaran: 87\%; (5) Tampilan Menyeluruh 87\%. Secara menyeluruh, penilaian ahli materi terhadap Komik Akuntansi dengan materi pokok persamaan dasar akuntansi ini jika dibuat rata-rata adalah sebesar $87 \%$, sehingga tingkat validasi dari segi kualitas penyampaian materi, komik ini dinilai sangat layak digunakan dalam pembelajaran SMA Kelas XI (Suharsimi Arikunto, 2010: 44).

b. Ahli Media Pembelajaran

Hasil penilaian oleh ahli media ditinjau dari acuan kriteria (Sukardjo, 2005: 53) adalah sebesar 105,50 sehingga dapat disimpulkan bahwa kualitas komik masuk pada kategori "sangat baik". Jika dilihat dari penilaian berdasarkan persentase tiap aspek; (1) Kebahasaan 90\%; (2) Penyajian 97\%; (4) Efek Media terhadap Strategi Pembelajaran 92\% dan (5) Tampilan Menyeluruh 91\%. Secara menyeluruh, penilaian ahli media terhadap Komik Akuntansi dengan materi pokok persamaan dasar akuntansi ini jika dibuat rata-rata adalah sebesar 92\%, sehingga tingkat validasi dari segi kualitasnya sebagai media pembelajaran, komik ini dinilai sangat layak digunakan dalam pembelajaran SMA Kelas XI (Suharsimi Arikunto, 2010: 44). 


\section{c. Guru SMA}

Hasil penilaian oleh ahli media ditinjau dari acuan kriteria Sukardjo adalah sebesar 169 sehingga dapat disimpulkan bahwa kualitas komik masuk pada kategori "sangat baik". Jika dilihat dari penilaian berdasarkan persentase tiap aspek; (1) Isi: 99\%; (2) Kebahasaan 100\%; (3) Penyajian 100\%; (4) Efek Media terhadap Strategi Pembelajaran 100\%; (5) Tampilan Menyeluruh 100\%. Secara menyeluruh, penilaian guru SMAN 1 Candimulyo terhadap Komik Akuntansi dengan materi pokok persamaan dasar akuntansi ini jika dibuat rata-rata adalah sebesar 99,39\%, sehingga tingkat validasi dari segi keterlaksanaan pada proses pembelajaran, komik ini dinilai sangat layak digunakan dalam pembelajaran SMA Kelas XI (Suharsimi Arikunto, 2010: 44).

\section{Penerapan/Uji coba pada pembelajaran}

Sebelum pelaksanaan uji coba produk (pembelajaran dengan menggunakan Komik Akuntansi), peneliti mengumpulkan data hasil tes siswa pada kompetensi dasar persamaan dasar akuntansi siswa kelas XI IPS 3 SMAN I Candimulyo sebelum penggunaan komik akuntansi. Data nilai yang diperoleh menunjukkan bahwa 9 siswa $(37,50 \%)$ lulus KKM dan 15 siswa $(62,50 \%)$ tidak lulus KKM. Rata-rata nilai tes ini adalah 63,13 dengan nilai tertinggi 97 dan nilai terendah 35 .

Uji coba dimulai dengan dengan pembelajaran kompetensi dasar persamaan dasar akuntansi menggunakan komik akuntansi dilanjutkan dengan post-test. Hasil post-test menunjukkan bahwa 23 siswa $(95,83 \%)$ lulus KKM dan 1 siswa $(4,17 \%)$ tidak lulus KKM. Rata-rata nilai kelas pada post-test ini sebesar 92,50 dengan nilai tertinggi kelas 100 dan nilai terendah 60. Hal ini cukup membuktikan bahwa produk pengembangan berupa Komik Akuntansi layak digunakan dalam pembelajaran akuntansi SMA Kelas XI, sesuai dengan pendapat dari E. Mulyasa (2007: 257), bahwa pembelajaran dikatakan tuntas apabila 75\% dari jumlah siswa di kelas telah mencapai ketuntasan belajar individu.

Selain data nilai, diperoleh juga data pengenai pendapat siswa dalam angket terbuka mengenai Komik Akuntansi. Berdasarkan rekapitulasi angket jawaban siswa yang dapat dilihat di lampiran 17 halaman 149, dapat disimpulkan bahwa sebesar 83,33\% siswa menyatakan bahwa petunjuk penggunaan komik telah jelas; 87,50\% siswa menyatakan bahwa penggunaan bahasa dalam komik mudah dipahami; $87,5 \%$ siswa menyatakan bahwa 


\section{Jurnal Pendidikan Akuntansi Indonesia, Vol. X, No. 2, Tahun 2012 Indriana Mei Listiyani \& Ani Widayati \\ Halaman $80-94$}

komik mendorong rasa ingin tahu mereka untuk mempelajari mata pelajaran akuntansi; 83,33\% siswa menyatakan bahwa komik telah menambah pengetahuan mereka; $100 \%$ siswa mengatakan bahwa komik telah menambah wawasan mereka mengenai mata pelajaran akuntansi; 83,33\% siswa menyatakan bahwa contoh yang digunakan telah jelas; dan 91,66\% siswa menyatakan bahwa tulisan yang digunakan pada komik mudah untuk dibaca.

\section{Penutup}

\section{Kesimpulan}

Berdasarkan analisis data dan pembahasan maka dapat disimpulkan:

a. Pengembangan komik sebagai media pembelajaran akuntansi telah melewati tujuh tahap pengembangan yaitu analisis kebutuhan, desain produk, produksi media, validasi dan analisis, revisi produk, uji coba produk serta analisis dan revisi akhir. Tahap validasi dan analisis meliputi validasi oleh ahli materi, ahli media dan Guru Akuntansi SMA. Uji coba produk dilaksanakan pada siswa kelas XI IPS 3 SMAN I Candimulyo. Sebelum diujicobakan, produk juga telah melewati dua kali revisi dan telah dinyatakan sesuai untuk digunakan dalam pembelajaran Akuntansi SMA kelas XI oleh ahli materi, ahli media pembelajaran dan praktisi mata pelajaran akuntansi.

b. Kelayakan/kualitas komik akuntansi, ditinjau dari aspek materi; kebahasaan; penyajian; efek media terhadap strategi pembelajaran dan tampilan menyeluruh. Hasil penilaian dari ahli materi, ahli media dan guru akuntansi terhadap semua aspek yang diukur, menyatakan hasil penilaian dengan kategori "Sangat Baik" dan "Layak". Berdasarkan hasil penilaian ini, artinya komik akuntansi layak untuk digunakan dalam pembelajaran akuntansi pada kompetensi dasar persamaan dasar akuntansi untuk siswa SMA kelas XI.

c. Siswa SMAN I Candimulyo selaku subjek uji coba produk menyatakan bahwa petunjuk penggunaan komik telah jelas, penggunaan bahasa dalam komik mudah dipahami, komik mendorong rasa ingin tahu mereka untuk mempelajari mata pelajaran akuntansi, komik telah menambah pengetahuan mereka, komik telah menambah wawasan mereka mengenai mata pelajaran akuntansi, contoh yang digunakan telah jelas dan tulisan yang digunakan pada komik mudah untuk dibaca.

d. Nilai post-test siswa subjek ujicoba untuk KD persamaan dasar akuntansi secara mayoritas mengalami peningkatan. Hal ini dibuktikan dengan peningkatan pencapaian 
KKM sebesar 50,33 \% dari 24 siswa (subjek uji subjek uji coba) dibandingkan dengan nilai tes subjek uji coba pada KD yang sama namun dengan pembelajaran tanpa komik akuntansi.

\section{Saran}

Berdasarkan kualitas produk, kelemahan dan keterbatasan penelitian yang telah dibahas sebelumnya, peneliti dapat memberikan beberapa saran pemanfaatan dan pengembangan produk lebih lanjut sebagai berikut:

a. Komik akuntansi ini memberikan variasi penyampaian materi yang dapat dimanfaatkan sebagai referensi guru dalam mengajar siswa maupun bagi siswa dalam belajar akuntansi secara mandiri.

b. Perlu adanya penelitian lebih lanjut seperti penelitian tindakan kelas ataupun penelitian pengembangan lebih lanjut untuk benar-benar mengukur efektivitas penggunaan produk, mengukur peningkatan tingkat pencapaian keseluruhan hasil belajar siswa mencakup aspek kognitif, afektif dan psikomotor serta memperbanyak fakta uji lapangan sehingga diperoleh lebih banyak bahan untuk memperbaiki produk dan pada akhirnya produk yang dihasilkan akan lebih baik lagi.

c. Sesuai dengan komentar dari ahli materi, komik akuntansi ini dapat dikembangkan pada materi lain yang lebih luas yaitu kompentensi dasar yang lain dengan waktu pengembangan yang lebih lama, sehingga cakupan materi komik lebih luas. Waktu penelitian yang lebih lama mendukung maksimalnya pembuatan desain serta revisi produk, sehingga produk yang dihasilkan menjadi lebih berkualitas.

\section{E. Daftar Pustaka}

Azhar Arsyad. (2011). Media Pembelajaran, Jakarta: PT RajaGrafindo Persada.

Borg, W. R \& Gall, M. D. (1983). Education Researsh. New York: Longman Bopy, J.

E. Mulyasa. (2007). Kurikulum Tingkat Satuan Pendidikan. Jakarta:Bumi Aksara.

I Wayan Satyasa. (2007). Model-Modal Pembelajaran Inovatif. Makalah. Disajikan dalam pelatihan PTK bagi guru Nusa Penida. Http://digilib.unnes.ac.id//. Diakses pada 19 Januari 2012 pukul 05.32. 
Muhibbin Syah. (2010). Psikologi Pendidikan Dengan Pendekatan Baru. Bandung: PT Remaja Rosdakarya Offset. . (2005). Media Pengajaran, Bandung: Sinar Baru Algensindo.

Romi Satria. (2008). $10 \quad$ Resep Sukses Bangsa Jepang. Http://danielmginting.blogspot.com/2008/07/10-resep-sukses-bangsa-jepang.html. Diakses pada 21 September pukul 08.58.

Suharsimi Arikunto. (2010). Manajemen Penelitian. Jakarta:Rineka Cipta.

Sukardjo. (2005). Evaluasi Pembelajaran.Modul PPs UNY. Yogyakarta:UNY.

Zaki Baridwan. (2008). Intermediet Accounting. Yogyakarta: BPFE Yogyakarta. 